\title{
Effect of Weather Years and Climatic Parameters on Yield of Maize Varieties under Sub-tropical Condition of Nepal
}

\author{
Tej Narayan Bhusal ${ }^{1}$ and Jagdish Timsina ${ }^{2}$ \\ ${ }^{1}$ Institute of Agriculture and Animal Science, Rampur, Chitwan, Nepal \\ ${ }^{2}$ IRRI-CIMMYT-ACIAR project, IRRI-Bangladesh Office, Dhaka, Bangladesh \\ e-mail:tnagr01@gmail.com
}

\begin{abstract}
Recent trends of climate change have raised serious concerns about the food production not only in regional levels but locally and globally. The well calibrated and validated Crop Simulation Model (CSM)-Crop Environment Resource Synthesis (CERES)-Maize (v 4.0) model and secondary crop data were used to test sensitivity of this model in subtropical condition of Nepal. The model was sensitive to climatic parameters (temperatures $\mathrm{CO}_{2}$ concentration and solar radiation) and weather years on yields of Rampur Composite, Upahar and Arun-4. The simulated yield for Rampur Composite and Arun- 4 were $13.41 \%$ and $16.89 \%$ higher, respectively in 2006 , while it was $0.12 \%$ higher for Upahar in 2005 than the yield of maize in 2007. Likewise, decrease in both maximum and minimum temperature by $4^{\circ} \mathrm{C}$ with respect to either solar radiation $\left( \pm 1 \mathrm{MJm}^{-2} \mathrm{day}^{-1}\right)$ and $\mathrm{CO}_{2}(+20 \mathrm{ppm})$ change or not change, maize yield increased by $11.72-49.11 \%$ as compared to base scenario while it was decreased by $32.22-2.83 \%$ for increase in both maximum and minimum temperature by $4^{\circ} \mathrm{C}$ along with either change in solar radiation $\left( \pm 1 \mathrm{MJm}^{-2} \mathrm{day}^{-1}\right)$ and $\mathrm{CO}_{2}(+20 \mathrm{ppm})$ or remains same. Results revealed that the temperature is more critical for yield potentiality of cultivars than any other climatic parameters. Screening out and adopting of new technology would be required to combat with changing climatic scenarios for attaining the potential yield of maize.
\end{abstract}

Key words: CSM-CERES-maize, simulation, calibration, validation, grain yield

\section{Introduction}

The six most widely grown crops in the world are wheat, rice, maize, soybean, barley and sorghum. For wheat, maize and barley, there is a clearly negative response of global yields to increased temperatures (Lobell \& Field 2007). Annual global temperatures have increased by $\sim 0.4^{\circ} \mathrm{C}$ since 1980 , with even larger changes observed in several regions (IPCC 2001).Global climate change, in the form of rising temperature and altered soil moisture, is projected to decrease the yield of food crops over the next 50 years (Thomson et al. 2005). Meanwhile, the simultaneous increase in $\mathrm{CO}_{2}$ concentration is predicted to stimulate crop production and offset these detrimental components of climate change (Thomson et al. 2005).
For the Indian Sub-continent, it is predicted that the mean atmospheric temperature will increase by 1-to $4^{\circ} \mathrm{C}$ (Sinha \& Sawaminathan 1991). Although the solar radiation received at the surface will be variable geographically, on average, it is expected to decrease by about 1\% (Hume \& Cattle 1990).

Crop simulation models, including CERES-Maize, which is available either as stand alone model, or within the Decision Support System for Agrotechnology Transfer (DSSAT) version 4 (a recently developed computer software program for decision support system) shell, can be used to understand the influence of climate change. Schultze et al. (1996) used CERES- 
Maize to evaluate the impact of climate change in Africa. After employing different climate scenarios for the $21^{\text {st }}$ century, they found that the $\mathrm{CO}_{2}$ enrichment counteracted the relatively modest changes in temperature and precipitation. Similarly, Iglesias (1994) demonstrated climate change scenarios in a greenhouse induced warmer climate, based on Goddard Institute for Space Science (GISS), Geophysical Fluid Dynamics Laboratory (GFDL), and United Kingdom Meteorological Office (UKMO) climate models, and projected an increase in evaporative rates and a more vigorous water cycle. Wolf (2002) considered a scenario with increased amounts of $\mathrm{CO}_{2}$ and showed that yields increased in proportion to other variable changes such as solar radiation and temperature. By using the CERES models, assessment on strategic management and climate change pattern have been done.

CERES model system allows user to screen new technology packages, such as a new cultivar or fertilizer management strategies, without spending excess time on expensive, time consuming field trials. By simulating outcomes of strategies, user can ask "what if" questions and explore the options. Sustainable agriculture requires tools that enable decision makers to explore the future. A decision support system must help users make choices today that result in desired outcomes, not only next year, but 10,25 , and 50 or more years into the future (International Benchmark Sites Network for Agrotchnology Transfor 1998). These models have been calibrated and validated across the world, including many countries in Asia (Timsina \& Humphreys 2003) and in N-W India (Timsina et al. 2004) and hence are suitable for sensitivity analysis to $\mathrm{CO}_{2}$ and climate change parameters. Hence, the present investigation was accomplished to understand the sensitivity of a model in terms of yield of maize varieties to changes in major climatic parameters as temperatures, $\mathrm{CO}_{2}$ and solar radiation and weather years.

\section{Methodology}

A field experiment was laid out in two factorial randomized complete block design at the agronomy farm of Institute of Agriculture and Animal Science (IAAS), Rampur, Chitwan during spring season of 2007. Field data of best performed treatment, 7.41 plants $\mathrm{m}^{-2}$ density for all three maize cultivars (Rampur Composite, Upahar and Arun-4), were used for calibration of a model. For each variety, the genetic coefficients were determined using $8^{\circ} \mathrm{C}$ as base temperature: (i) Degree days (base $8^{\circ} \mathrm{C}$ ) from emergence to end of juvenile phase (P1); (ii) Photoperiod sensitivity coefficients (01.0) (P2); (iii) Degree days (base $8^{\circ} \mathrm{C}$ ) from silking to physiological maturity (P5); (iv) Potential kernel number (G2); (v) Kernel filling rate coefficients (G3) and (vi) Degree days required for a leaf tip to emerge (Phyllochron interval) $\left({ }^{0} \mathrm{C} \mathrm{d}\right)$ (PHINT). These determined genetic coefficients of three varieties used for the validation with their respective varieties. Model validation was illustrated by comparison of the model performance against data collected on maximum leaf area index (LAI max), days to anthesis and maturity, tops weight at maturity and grain yield for all nine treatments (4.76 plants $\mathrm{m}^{-2}, 5.56$ plants $\mathrm{m}^{-2}$ and 6.36 plants $\mathrm{m}^{-2}$ for all varieties). Model evaluation for development, yield and time-course of growth was performed using root mean square error (RMSE) and index of agreement (D-index) as suggested by Willmott (1982) and Willmott et al. (1985).

Changes in $\mathrm{CO}_{2}$ concentration, temperature and solar radiation were considered to test the sensitivity of yield and growth of maize varieties simulated by CSMCERES-Maize model, embodied within the DSSAT (v. 4 ), to the climate parameters. Density at 6.35 plants $\mathrm{m}^{-}$ 2 for all 3 cultivars was taken as 'base or standard scenario'. Weather data of 2007 was used for 'base scenario' or 'standard treatment' and various changes to $\mathrm{CO}_{2}$ and climatic parameters were made. Model was first run for 3 years of weather data from Rampur to observe the sensitivity of the models to various weather years. Sensitivity of the model to climate change parameters was carried out for an increase or decrease in maximum and minimum temperature by $4^{\circ} \mathrm{C}$, increase or decrease in solar radiation by $1 \mathrm{MJm}^{-2} \mathrm{day}^{-}$ ${ }^{1}$ and for an increase of $\mathrm{CO}_{2}$ concentration by $20 \mathrm{ppm}$ to the 2007 weather data. The climate change simulation was accomplished by using the environmental modification section of File-X used to run the model (Jones et al. 2003).

\section{Results and Discussion \\ Derivation of genetic coefficients}

The genetic coefficients were adjusted for three maize cultivars (Table 1) by running the models several times by trial and error methods. Genetic coefficient values of these varieties vary due to variation in growth and 
Tej Narayan Bhusal \& Jagdish Timsina/Effect of Weather..

development rate at different phase. These estimated genetic coefficients were then used for validation and further analysis/evaluation of the model. The simulated anthesis day, days to physiological maturity and grain yields for three cultivars were accurately found to be close to the observed values.

Table 1. Estimated genetic coefficients of maize varieties under different plant densities during 2007 in Rampur

\begin{tabular}{|c|c|c|c|c|c|c|c|c|c|c|c|c|}
\hline \multirow[t]{2}{*}{ Cultivars } & \multicolumn{6}{|c|}{ Genetic coefficients } & \multicolumn{2}{|c|}{$\begin{array}{l}\text { Anthesis } \\
\text { day }\end{array}$} & \multicolumn{2}{|c|}{$\begin{array}{l}\text { Physiological } \\
\text { maturity day }\end{array}$} & \multicolumn{2}{|c|}{$\begin{array}{l}\text { Grain yield } \\
\left(\mathrm{kg} \mathrm{ha}^{-1}\right)\end{array}$} \\
\hline & $\mathbf{P 1}$ & P2 & P5 & G2 & G3 & PHINT & Sim. & Obs. & Sim. & Obs. & Sim. & Obs. \\
\hline Rampur Composite & 285.7 & 0.50 & 869.5 & 752.4 & 8.71 & 45 & 68 & 68 & 109 & 109 & 4538 & 4538 \\
\hline Upahar & 300.0 & 0.50 & 880.0 & 712.0 & 8.75 & 45 & 70 & 70 & 112 & 112 & 5052 & 5052 \\
\hline Arun-4 & 233.0 & 0.50 & 784.0 & 665.7 & 8.93 & 48 & 63 & 63 & 100 & 100 & 4052 & 4052 \\
\hline
\end{tabular}

Sim. - Simulated, Obs.- Observed
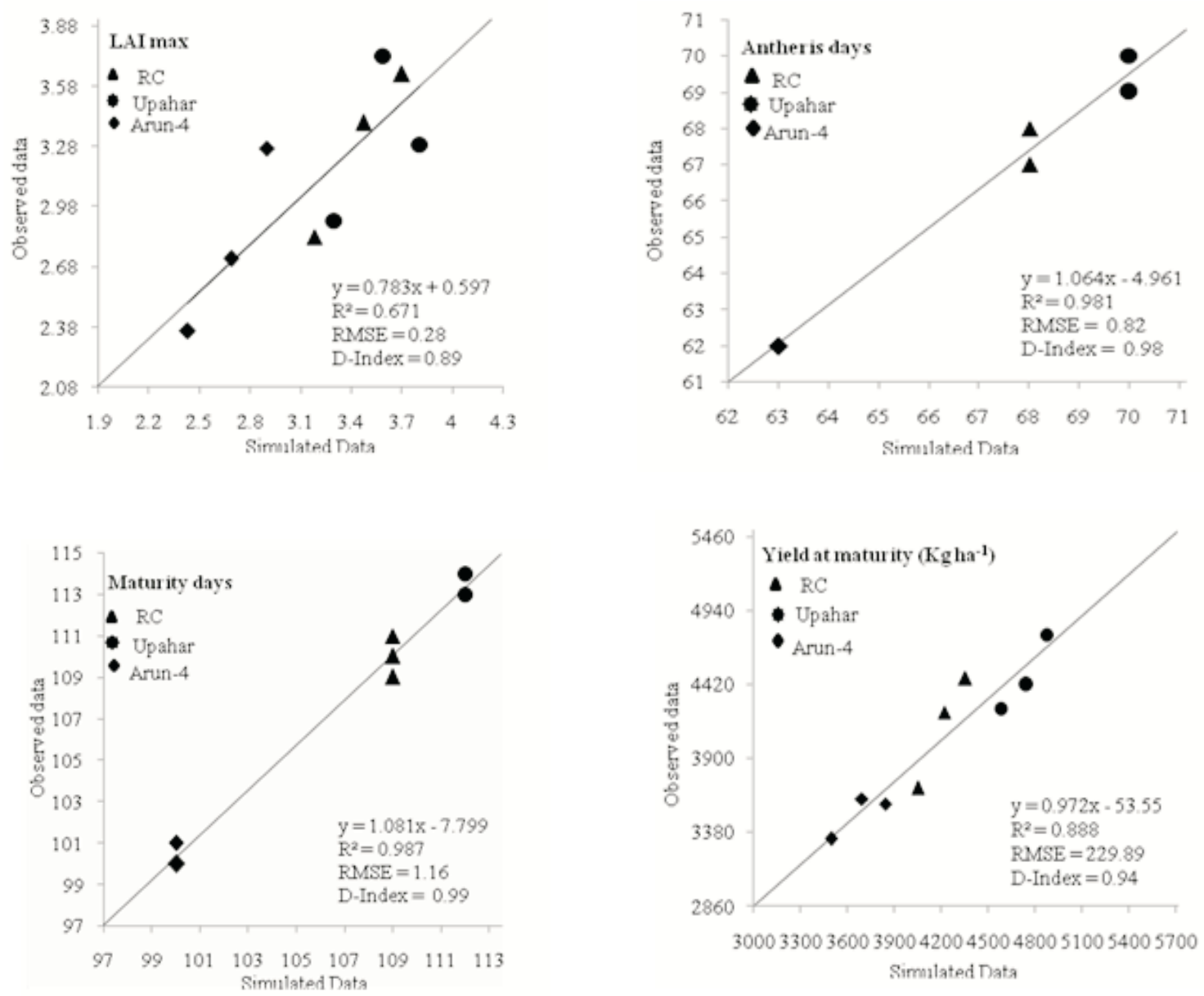

Fig. 1. Simulated and observed $\mathrm{LAI}_{\max }$, anthesis days, maturity days, and grain yield $\left(\mathrm{kg} \mathrm{ha}^{-1}\right)$ for three maize cultivars 


\section{Model validation}

Observation on anthesis days and physiological maturity days, LAImax, unit weight of grain, tops weight at maturity and grain yield were used for the model validation. The validation results showed that the CERES-Maize model could be safely used as assistant tools to study the impact of change in climatic parameters on the yield of maize crop.

Simulation results in maize showed good agreement between observed and predicted maximum LAI (RMSE of 0.28 and D-index of 0.89 ), anthesis days (RMSE $=0.82$ days and D-index $=0.98)$, maturity days $(\mathrm{RMSE}=1.16$ days and D-index $=0.99)$, and grain yield $\left(\mathrm{RMSE}=229.89 \mathrm{~kg} \mathrm{ha}^{-1}\right.$, and D-index $=$ 0.94) (Fig. 1). Similarly, unit weight of grain (RMSE of $0.01 \mathrm{~g}$ and D-index of 0.79 ) was well simulated with observed value. However, tops wt at maturity showed fairly satisfactory agreement (RMSE = $5437.15 \mathrm{~kg} \mathrm{ha}^{-1}$ and D-index $=0.48$ ) between observed and predicted values as simulated values were under predicted to all observed yields. Some of the discrepancy might be due to the variations in initial soil nitrogen status indicating low to moderate soil fertility as it was found in the research field.

\section{Sensitivity of CSM-CERES-Maize to weather years}

The model was run for 3 years of weather data (20052007) from NMRP, Rampur, Chitwan. Results showed that the simulated yields of three varieties of maize were sensitive to various weather years. Simulation clearly indicated that maize yield was higher for Rampur Composite and Arun-4 in 2006 (13.41 \% for RC and $16.89 \%$ for Arun-4 over 2007, the base year) and for Upahar it was non-significantly higher in 2005 (0.12\% over 2007, base year). There were, however, not marked differences on days to anthesis and to physiological maturity for different weather (Table 2). The higher yields of grain in 2005 and 2006 were related to ambient weather conditions in terms of average daily temperature, PAR and rainfall (Fig. 2).

Throughout the growing season, maize received higher daily PAR, ambient and a bit higher average daily temperature and more or less consistent precipitation on active growing stage in the year 2005 and 2006 over base year. The growing condition has altered the grain yield of maize varieties. Cirilo \& Andrade (1994) reported that maize kernels yield was closely associated with kernels number plant ${ }^{-1}$ at harvest due to variation in growth conditions. Maize kernels number plant ${ }^{-1}$ was positively related to intercept photosynthetically active radiation and growth rate (Kiniry \& Knievel 1995, Ouda \& Swilam 2003) and negatively related to temperature (Ouda \& Swilam 2003).

Table 2. Sensitivity of simulated yields and phenology of maize cultivars to weather years

\begin{tabular}{|c|c|c|c|c|c|c|c|}
\hline \multirow[t]{2}{*}{ Weather years } & \multirow[t]{2}{*}{ Treatments } & \multicolumn{2}{|c|}{ Grain yield (kg ha' $\left.{ }^{-1}\right)$} & \multirow[t]{2}{*}{ Percentage yield } & \multirow{2}{*}{$\begin{array}{l}\text { Anthesis } \\
\text { (days) }\end{array}$} & \multicolumn{2}{|c|}{$\begin{array}{l}\text { Physiological } \\
\text { maturity (days) }\end{array}$} \\
\hline & & Obs. & Sim. & & & Obs. & Sim. \\
\hline \multirow[t]{3}{*}{$2007^{\mathrm{a}}$} & $\mathrm{RC}$ & 4460 & 4353 & 100.00 & 68 & 109 & 109 \\
\hline & Upahar & 4770 & 4868 & 100.00 & 70 & 112 & 112 \\
\hline & Arun-4 & 3576 & 3841 & 100.00 & 63 & 100 & 100 \\
\hline \multirow[t]{3}{*}{2006} & $\mathrm{RC}$ & - & 4971 & 113.41 & 67 & - & 109 \\
\hline & Upahar & - & 4761 & 97.80 & 69 & - & 111 \\
\hline & Arun-4 & - & 4490 & 116.89 & 63 & - & 100 \\
\hline \multirow[t]{3}{*}{2005} & $\mathrm{RC}$ & - & 4855 & 111.53 & 65 & - & 107 \\
\hline & Upahar & - & 4874 & 100.12 & 67 & - & 109 \\
\hline & Arun-4 & - & 3903 & 101.61 & 61 & - & 100 \\
\hline
\end{tabular}

${ }^{a}$ standard year, Sim. - Simulated, Obs.- Observed 
Tej Narayan Bhusal \& Jagdish Timsina/Effect of Weather.

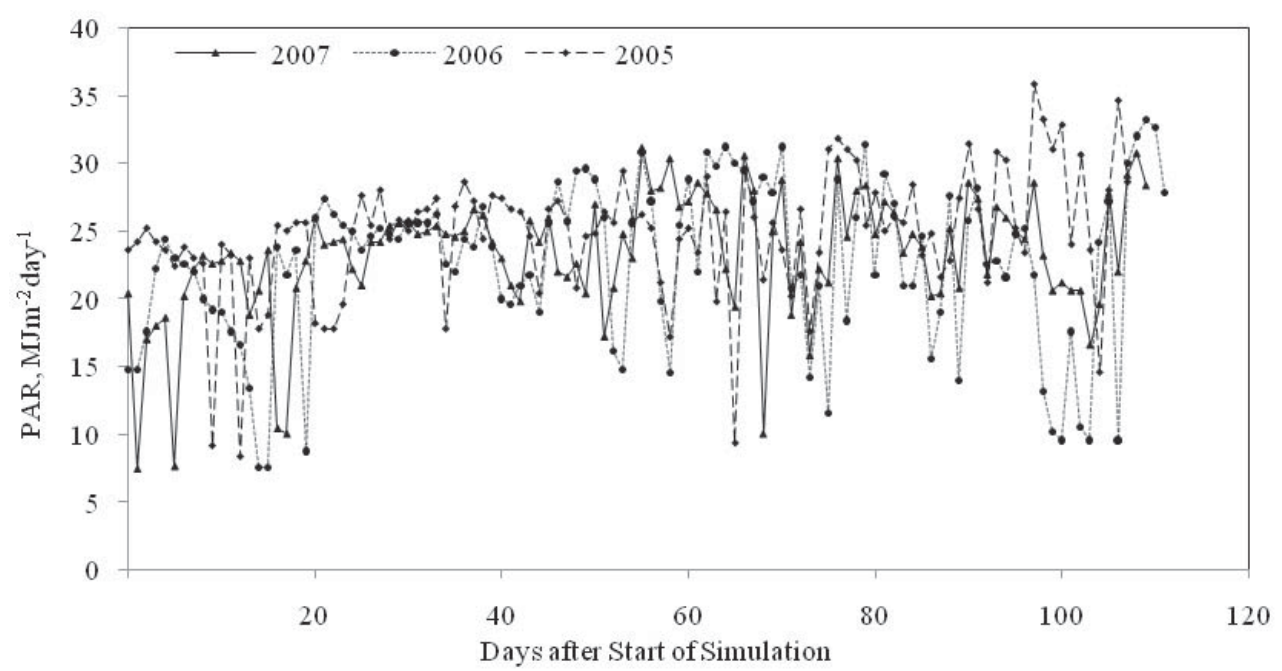

(a)

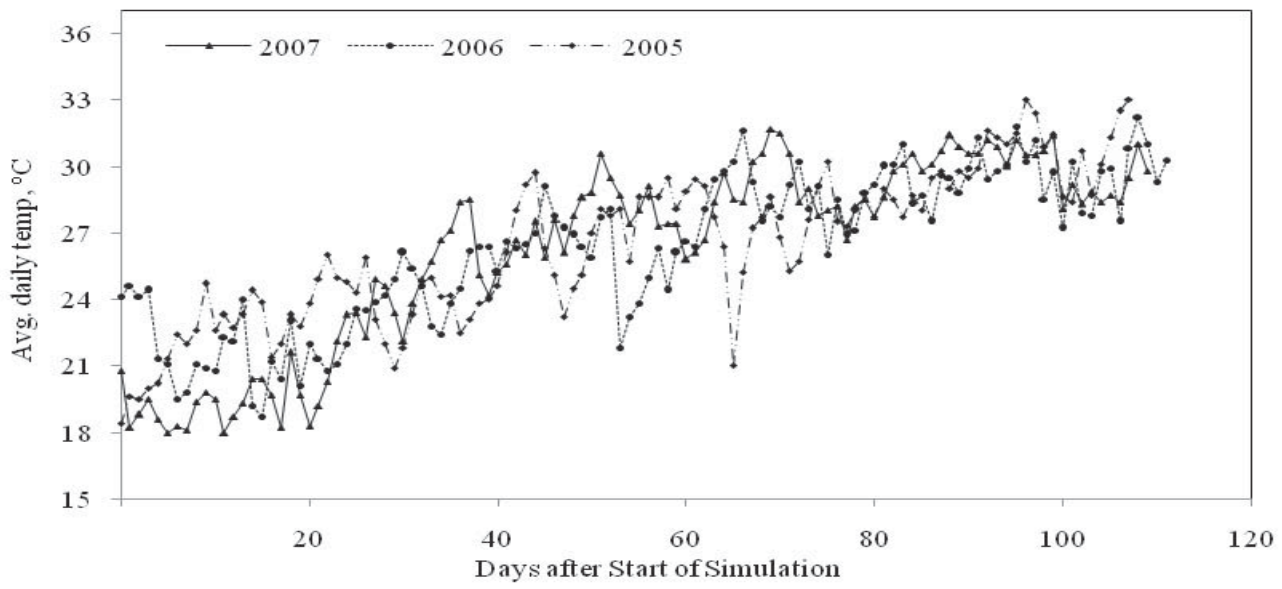

(b)

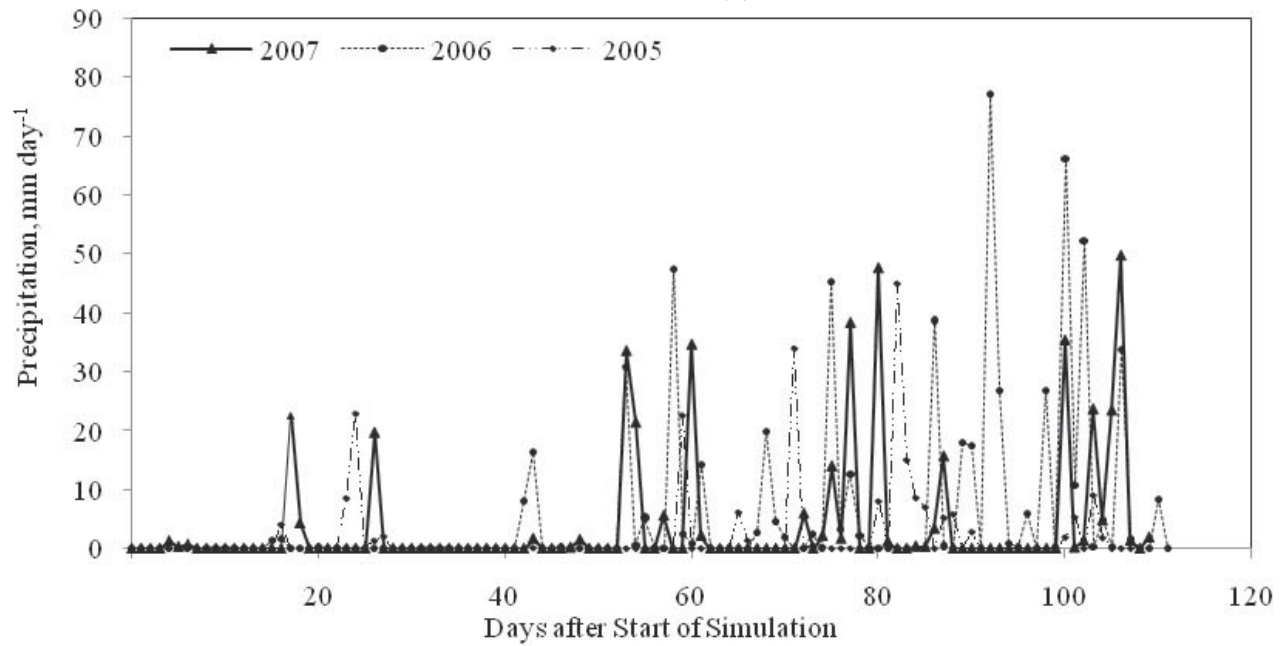

(c)

Fig. 2. Simulated (a) daily photosynthetically active radiation $\left(\mathrm{MJm}^{-2} \mathrm{day}^{-1}\right)$, (b) average daily temperature $\left({ }^{\circ} \mathrm{C}\right)$, and (c) daily precipitation (mm) during maize season 


\section{Sensitivity to climate parameters}

Various scenarios of temperature, carbon dioxide concentration and solar radiation were selected for sensitivity analysis of yields simulated by CERES-Maize for each cultivar (Table 3). Compared to simulated yield of standard treatment, the increase in yield was 39.90\%, 17.83\% and 29.54\% for Rampur Composite, Upahar and Arun-4, respectively, with the decrease in both maximum and minimum temperature by $4^{\circ} \mathrm{C}$, but, the increase in both maximum and minimum temperature by $4^{\circ} \mathrm{C}$ actually decreased the yield by $12.5 \%, 25.56 \%$ and $20.13 \%$ for Rampur Composite, Upahar and Arun-4, respectively. Likewise, it was found increased in crop duration and yield for decreased in temperature. The decrease in crop growth was 12-14 days irrespective to varieties for increased temperature while increase in crop growth was 18-20 days irrespective of varieties for decreased temperature (Table 3). Temperature primarily affected growth duration with lower temperature increasing the length of time that the crop could intercept radiation. The solar radiation response was related to the amount of incident radiation and to the fraction of radiation intercepted by the crop. In the tropics, high temperature decreased the duration of growth and grain yield, despite high levels of radiation (Muchow et al. 1990). However, higher temperatures generally decrease yield by speeding up a plant's development so that it matures sooner (thus reducing the period available for yield production); they often also exacerbate stress on water resources that are essential for crop growth. Yield decreases would be greatest if higher temperatures occur during the period when the maize ears are swelling (Southworth et al. 2000, Jones \& Thornton 2003). Temperature affects the duration of crop growth, through its effect on enzymatic reactions in the plant (Gardner et al. 1985).

Table 3. Sensitivity analysis of maize cultivars with changes in temperature, solar radiation and $\mathrm{CO}_{2}$ concentration

\begin{tabular}{|c|c|c|c|c|c|c|c|}
\hline $\begin{array}{l}\text { Max temp } \\
\left({ }^{\circ} \mathrm{C}\right)\end{array}$ & $\begin{array}{l}\text { Min temp } \\
\left({ }^{\circ} \mathrm{C}\right)\end{array}$ & $\begin{array}{l}\mathrm{CO}_{2} \text { conc. } \\
(\mathrm{ppm})\end{array}$ & $\begin{array}{l}\text { Solar radiation } \\
\left(\mathbf{M J m}^{-2} \text { day }^{-1}\right)\end{array}$ & Treatments & $\begin{array}{l}\text { Simulated yield } \\
\left(\mathrm{kg} \mathrm{ha}^{-1}\right)\end{array}$ & $\begin{array}{l}\text { Percentage } \\
\text { yield }\end{array}$ & $\begin{array}{l}\text { Growth duration } \\
\text { (days) }\end{array}$ \\
\hline \multirow[t]{3}{*}{$+0^{\mathrm{a}}$} & \multirow[t]{3}{*}{+0} & \multirow[t]{3}{*}{330} & \multirow[t]{3}{*}{+0} & $\mathrm{RC}$ & 4353 & 100.00 & 109 \\
\hline & & & & Upahar & 4868 & 100.00 & 112 \\
\hline & & & & Arun-4 & 3841 & 100.00 & 100 \\
\hline \multirow[t]{3}{*}{+4} & \multirow[t]{3}{*}{+4} & \multirow[t]{3}{*}{330} & \multirow[t]{3}{*}{+0} & $\mathrm{RC}$ & 3809 & 87.50 & 96 \\
\hline & & & & Upahar & 3624 & 74.44 & 98 \\
\hline & & & & Arun-4 & 3068 & 79.87 & 88 \\
\hline \multirow[t]{3}{*}{-4} & \multirow[t]{3}{*}{-4} & \multirow[t]{3}{*}{330} & \multirow[t]{3}{*}{+0} & $\mathrm{RC}$ & 6090 & 139.90 & 128 \\
\hline & & & & Upahar & 5736 & 117.83 & 132 \\
\hline & & & & Arun-4 & 4976 & 129.54 & 119 \\
\hline \multirow[t]{3}{*}{+4} & \multirow[t]{3}{*}{+4} & \multirow[t]{3}{*}{+20} & \multirow[t]{3}{*}{+0} & $\mathrm{RC}$ & 3902 & 89.63 & 96 \\
\hline & & & & Upahar & 3650 & 74.97 & 98 \\
\hline & & & & Arun-4 & 3105 & 80.83 & 88 \\
\hline \multirow[t]{3}{*}{-4} & \multirow[t]{3}{*}{-4} & \multirow[t]{3}{*}{+20} & \multirow[t]{3}{*}{+0} & $\mathrm{RC}$ & 6113 & 140.43 & 128 \\
\hline & & & & Upahar & 5757 & 118.26 & 130 \\
\hline & & & & Arun-4 & 5000 & 130.17 & 119 \\
\hline \multirow[t]{3}{*}{+4} & \multirow[t]{3}{*}{+4} & \multirow[t]{3}{*}{+20} & \multirow[t]{3}{*}{+1} & $\mathrm{RC}$ & 4243 & 97.47 & 96 \\
\hline & & & & Upahar & 3955 & 81.24 & 98 \\
\hline & & & & Arun-4 & 3361 & 87.50 & 88 \\
\hline \multirow[t]{3}{*}{+4} & \multirow[t]{3}{*}{+4} & \multirow[t]{3}{*}{+20} & \multirow[t]{3}{*}{-1} & $\mathrm{RC}$ & 3373 & 77.48 & 96 \\
\hline & & & & Upahar & 3300 & 67.78 & 98 \\
\hline & & & & Arun-4 & 2843 & 74.01 & 88 \\
\hline \multirow[t]{3}{*}{-4} & \multirow[t]{3}{*}{-4} & \multirow[t]{3}{*}{+20} & +1 & $\mathrm{RC}$ & 6491 & 149.11 & 128 \\
\hline & & & & Upahar & 6103 & 125.36 & 130 \\
\hline & & & & Arun-4 & 5535 & 144.10 & 120 \\
\hline-4 & -4 & +20 & -1 & $\mathrm{RC}$ & 5774 & 132.64 & 128 \\
\hline & & & & Upahar & 5439 & 111.72 & 130 \\
\hline & & & & Arun-4 & 4643 & 120.87 & 119 \\
\hline
\end{tabular}

${ }^{\mathrm{a}}$ standard treatment 
Tej Narayan Bhusal \& Jagdish Timsina/Effect of Weather.

Elevated $\mathrm{CO}_{2}$ by $20 \mathrm{ppm}$ along with increased temperature had resulted in decrease in grain yield by $10.37 \%, 25.03 \%$ and $19.17 \%$, respectively, for Rampur Composite, Upahar and Arun-4. But, in combination with decreased temperature, there was increased in yield by $40.43 \%, 18.26 \%$ and $30.17 \%$, respectively for Rampur Composite, Upahar and Arun-4. Simulated grain yield was decreased by $2.53 \%, 18.76 \%$ and $12.5 \%$, respectively, for Rampur Composite, Upahar and Arun-4, when there was increased in $1 \mathrm{MJm}^{-2} \mathrm{day}^{-1}$ solar radiation along with the increased temperature $\left(+4^{\circ} \mathrm{C}\right)$ and $\mathrm{CO}_{2}$ concentration $(+20 \mathrm{ppm})$. Increased in temperature by $4^{\circ} \mathrm{C}$ along with increase in $\mathrm{CO}_{2}$ concentration $(+20$ $\mathrm{ppm})$ and decrease in solar radiation $\left(-1 \mathrm{MJm}^{-2} \mathrm{day}^{-}\right.$ $\left.{ }^{1}\right)$ resulted decreasing yield by $22.52 \%, 32.22 \%$ and 25.99\% for Rampur Composite, Upahar and Arun-4, respectively. Decreased temperature $\left(-4^{\circ} \mathrm{C}\right)$ accompanied with increase in $\mathrm{CO}_{2}$ concentration $(+20 \mathrm{ppm})$ and increase in solar radiation $\left(+1 \mathrm{MJm}^{-}\right.$ ${ }^{2}$ day $^{-1}$ ) had increased the simulated yield of Rampur Composite by $49.11 \%$; Upahar by $25.36 \%$ and Arun4 by $44.10 \%$. Similarly, decreased temperature $\left(-4^{\circ} \mathrm{C}\right)$ accompanied with increase in $\mathrm{CO}_{2}$ concentration $(+20 \mathrm{ppm})$ and decrease in solar radiation $\left(-1 \mathrm{MJm}^{-}\right.$ ${ }^{2}$ day $^{-1}$ ) had also increased the simulated yield of Rampur Composite by 32.64\%; Upahar by $11.72 \%$ and Arun- 4 by $20.87 \%$. The decrease in yield due to decrease in solar radiation might be due to negative impact on the leaf area index of the crop as described by Reddy and Reddi (2005).

Decreased temperature accompanied with increased in $\mathrm{CO}_{2}$ concentration and solar radiation resulted in longer crop duration and higher yield (Table 3). In general, higher $\mathrm{CO}_{2}$ levels in the atmosphere, increase growth and yield, mainly through their effect on the crop's photosynthetic processes (Hendrey \& Kimball 1994)). Enzymes of both the $\mathrm{C}_{4}$ cycle and Calvin cycle in maize were consistently lower under elevated $\mathrm{CO}_{2}$, with malate dehydrogenase (“37\%) and glyceraldehyde-3phosphate dehydrogenase activities (" $29 \%$ ) declining to the greatest extent in young leaves (Maroco et al. 1999). Conversely, theoretical treatment of $\mathrm{C}_{4}$ photosynthesis suggested that differences in either leakiness or direct $\mathrm{CO}_{2}$ fixation are unlikely to play a significant role in the responsiveness of $\mathrm{C}_{4}$ photosynthesis to high $\mathrm{CO}_{2}$ (Ghannoum et al. 2000).
CERES-Maize model was found sensitive towards changing scenarios like weather years, $\mathrm{CO}_{2}$ and climatic parameters. Sensitivity tests showed that weather year affect the simulated yield of maize and the year 2006 was good for Rampur Composite and Arun-4 while detrimental for Upahar. Likewise, increase in temperature, irrespective to increase in $\mathrm{CO}_{2}$ and increase or decrease in solar radiation have reduced the simulated yield and crop growth duration. In addition, decrease in temperature, irrespective to increase in $\mathrm{CO}_{2}$ and increase or decrease in solar radiation have increased the simulated yield and crop growth duration. Detrimental impacts resulted when the temperature increased since it reduced the yield and duration of crop. Hence, through closer investigation on model processes new technology can be explored using CERES model for combating with the changing climatic scenarios.

\section{Acknowledgements}

Acknowledgements are highly accorded to NARDEF for providing financial support and NMRP for providing agrometerological data to run the model. The authors like to express special thank to Soil Science Division, NARC, Khumaltar. Thanks also go to Dr. S.K. Sah, Mr. L.P. Amgai, Dr. N.R. Devkota and Dr. Gerrit Hoogenboom for their inspiration and continuous guidelines to run the model.

\section{References}

Cirilo, A.G. and F.H. Andrade. 1994. Sowing date and maize productivity: II Kernels number determination. Crop Science 34: 1044-1046.

Gardner, F.P., R.B. Pearce and R.L. Mitchell. 1985. Physiology of Crop Plants. Iowa State University Press. Ames, USA.

Ghannoum, O., S. von Caemmerer, L.H. Ziska and J.P. Conroy. 2000. The growth response of $\mathrm{C}_{4}$ plants to rising atmospheric $\mathrm{CO}_{2}$ partial pressure: a reassessment. Plant Cell Environment 23: 931-942.

Hendrey, G. R. and B. A. Kimball. 1994. The FACE program. Agriculture and Forest Meteorology 70: 3-14.

Hume, C.J. and H. Cattle. 1990. The green house effect: Meteorological mechanisms and methods. Outlook Agriculture 19: 17-23.

International Benchmark Sites Network for Agrotchnology Transfor. 1998. DSSAT Information page (http:// www.icasa.net/dssat/index.html).

Iglesias, A. 1994. Climate change impact simulation and management strategies of two reference crops: Wheat 
and maize. Ph.D. dissertation. Univ. Politecnica de Madrid, Madrid, Spain.

IPCC. 2001. Climate change 2001: Impacts, adaptation and vulnerability. Intergovernmental Panel on Climate Change Working Group 2.

Jones, J.W., G. Hoogenboon, C.H. Porter, K.J. Boote, W.D. Batchelor, L.A. Hunt, P.W. Wilkens, V. Singh, A.J. Gijsman and J.T. Ritchie. 2003. The DSSAT cropping system model. European Journal of Agronomy 18: 235-265.

Jones, P. G. and P. K. Thornton. 2003. The potential impacts of climate change on maize production in Africa and Latin America in 2055. Global Environmental Change 13:51-59.

Kiniry, J.R. and D.P. Knievel. 1995. Response of maize kernels number to solar radiation intercepted soon after anthesis. Agronomy Journal 87: 228-234.

Lobell, D.B. and C.B. Field. 2007. Global scale climatecrop yield relationships and the impacts of recent warming. Environmental Research Letter Vol. 2

Maroco, J.P., G.E. Edwards and M.S.B. Ku. 1999. Photosynthetic acclimation of maize to growth under elevated levels of carbon dioxide. Planta 210:115-125.

Muchow, R.C., T.R. Sinclair and J.M. Bennett. 1990. Temperature and solar radiation effects on potential maize yields across locations. Agronomy Journal 82:338-342.

Ouda, A.H. and S.M. Swilam. 2003. Prediction of maize kernels number through some weather parameters. Ann. Agric. Sci. Moshtohor 41:39-47.

Reddy, T.Y. and G.H. Reddi. 2005. Principles of agronomy. Kalyani Publishers, Ludhiana, India. pp. 54-326.

Schultze, R.E., G.A. Kiker and R.P. Kunz. 1996. Global climate change and agricultural productivity in Southern Africa: thought for food and food for thought. In: Climate change and world food security (Ed. T.E.
Downing). North-Atlantic Treaty Organization ASI Series, vol. 137. Springer-Verlag, Berlin, Pp. 421-447.

Sinha, S.K. and M.S. Swaminathan. 1991. Deforestation, climate change and sustainable nutrition security: a case study of India. Climate Change 19:201-209.

Southworth, J., J. C. Randolph, M. Habeck, O. C. Doering, R. A. Pfeifer, D. G. Rao and J. J. Johnston. 2000. Consequences of future climate change and changing climate variability on maize yields in the Midwestern United States. Agriculture Ecosystem and Environment 82:139-158.

Thomson, A.M., R.A. Brown, N.J. Rosenberg, R.C. Izaurralde and V. Benson. 2005. Climate change impacts for the conterminous USA: An integrated assessment. Part 3. Dryland production of grain and forage crops. Climate Change 69:43-65.

Timsina, J. and E. Humphreys. 2003. Performance and application of CERES and SWAGMAN destiny ${ }^{\circledR}$ models for rice-wheat cropping systems of Asia and Australia: a review. CSIRO Land and Water Technical Report 16/03, Australia.

Timsina, J., H. Pathak, E. Humphreys, D. Godwin, B. Singh, A.K. Shukla and U. Singh. 2004. Evaluation and yield gap analysis in rice using CERES-Rice vers 4.0 in north-west India. In: Procedding (CD-ROM) of $4^{\text {th }}$ International Crop Science Congress (September $26-$ October 1, 2004), Brisbane, Australia.

Willmott, C.J. 1982. Some comments on the evaluation of model performance. Bulletin of Amesterdam Meteorological Societies 63:1309-1313.

Willmott, C.J., S.G. Ackleson, R.E. Davis, J.J. Feddema, K.M. Klink, D.R. Legates, J. O'connell and C.M. Rowe. 1985. Statistics for the evaluation and comparison of models. Journal of Geophysical Research of Oceans 90:8995-9005.

Wolf, J. 2002. Comparison of two soyabean simulation models under climate change. I. Model calibration and sensitivity analyses. Climate Research 20:55-70. 